\title{
Petrographic analysis of Usulután and Rosales Zone Engraved ceramics from two Tempisque period (300 B.C. - 500 A.D.) sites on Culebra Bay, Costa Rica
}

\author{
Lorelei Platz
}

Universidad de Costa Rica

loreleiplatz@gmail.com

\begin{abstract}
As a preliminary study, the primary objective to this investigation is to provide insight into the paste composition of two ceramic types-Usulután and Rosales Zone Engraved-from the sites of Loma Corral 3 (G-776 LC3) and Manzanillo (G-430 MZ) in the Bay of Culebra, Guanacaste. Petrographic analysis of Usulután and Rosales Zone Engraved ceramics from the Tempisque period (300 B.C.-500 A.D.) suggest that groups in the Bay of Culebra were participating in exchange of ceramics and ceramic techniques. Most recent investigations have demonstrated that Usulután was manufactured in Nicaragua, although it is still unclear as to whether or not it was also manufactured in Costa Rica.
\end{abstract}

Keywords: Loma Corral 3, Manzanillo, Guanacaste, minerology, Greater Nicoya, exchange systems.

Análisis petrográfico de cerámicas de los tipos Usulután y Rosales Esgrafiado, de dos sitios del periodo Tempisque (300 A.C. -500 D.C.) en la bahía Culebra, Costa Rica

Resumen: En este estudio preliminar el objetivo principal es determinar la composición de la pasta de dos tipos de cerámica, el Usulután Negativo y el Rosales Esgrafiado, recuperados en los sitios Loma Corral 3 (G-776 LC3) y Manzanillo (G-430MZ) en la bahía Culebra, Guanacaste. El análisis petrográfico de la cerámica Usulután y Rosales Esgrafiado del período Tempisque (300 a.C. -500 d.C.) sugiere que los grupos en la bahía de Culebra estaban participando en el intercambio, tanto de cerámicas como de las técnicas de manufactura. Las investigaciones más reciente han demostrado que Usulután fue manufacturado en Nicaragua, pero todavía hay una duda si fue manufacturando en Costa Rica.

Palabras clave: Loma Corral 3, Manzanillo, Guanacaste, mineralogía, Gran Nicoya, sistemas de intercambio.

Cuadernos de Antropología

Enero-Junio 2015, 25(1), 3-23

DOI: $10.15517 /$ cat.v25i1.19269

Recibido: 12-07-2014 / Aceptado: 24-03-2015

Revista del Laboratorio de Etnología María Eugenia Bozzoli Vargas

Escuela de Antropología, Universidad de Costa Rica

http://revistas.ucr.ac.cr/index.php/antropologia

ISSN 2215-356X

c) (i) (-) Cuadernos de Antropología está bajo una licencia Creative Commons Attribution-NonCommercial-ShareAlike 3.0 


\section{Introduction ${ }^{1}$}

This paper reviews the use of petrography to better understand potential manufacturing regions and exchange systems for two important Tempisque period (300 B.C. -500 A.D.) pottery styles from the Nicoya region of northwest Costa Rica. This analysis focused specifically on paste composition of the highly diagnostic Rosales Zone Engraved and Usulután ceramic types recovered from the sites of Loma Corral 3 (G-776 LC3) and Manzanillo (G-430MZ), both located on Culebra Bay. Because this is the first preliminary petrographic analysis from either of these sites, only two decorated serving-ware types were sampled, as well as a "locally produced" monochrome sample set used as a control group. An earlier study of Usulután and Rosales ceramics from the site of La Arenera, located near modern day Managua city, Nicaragua (Dennett et al., 2011), provided additional comparative samples and resulting data, further expanding the breadth and strength of this investigation. Figure 1 shows the location of the Greater Nicoya archaeological region, including Culebra Bay and the comparative site of La Arenera.

This study draws upon the anthropological concept of a gift-based exchange system following Mauss (1923). In many respects, utilizing a gift-based system to explain and better understand the exchange systems is in many ways a more useful method compared to the traditional models of exchange and trade developed by Renfrew (1975). The sporadic appearance of Usulután in the Greater Nicoya region lacks the structure of a formalized exchange system. Instead, I have drawn upon the concept of Gateway Communities and a dendritic distribution system, as conceptualized by Hirth (1978), to better understand the distribution and flow of ceramic materials from probable manufacturing points to the location of consumers. The concept of a dendritic system with modifications to allow for bidirectional movement and multiple manufacturing centres is a much more fluid means of understanding exchange and gifting between different groups. Platz (2014) provides a brief example of how this system could be applied to Rosales Zone Engraved and Usulután, with consideration of whether it was the final product or perhaps artisans that were moving between manufacturing and consuming centres.

Here I begin with a brief review of previous petrographic studies in the Greater Nicoya region, as well as an overview of the two study sites chosen for this analysis and a brief introduction to the primary ceramic types used in this study. This is followed by an explanation of the methodology used, a description of the petrographic results, and a closing discussion of the results and how they have served to inform on the pre-Columbian manufacture and exchange of Rosales Zone Engraved and Usulután ceramics.

1 This article is the result of the masters thesis in Anthropology, titled Un sistema de intercambio macroregional en el period Tempisque (300 a.C. - 500 d.C.): Estructura composicional de tres tipos cerámicos encontrados en la bahía de Culebra, Costa Rica (Platz, 2014). 


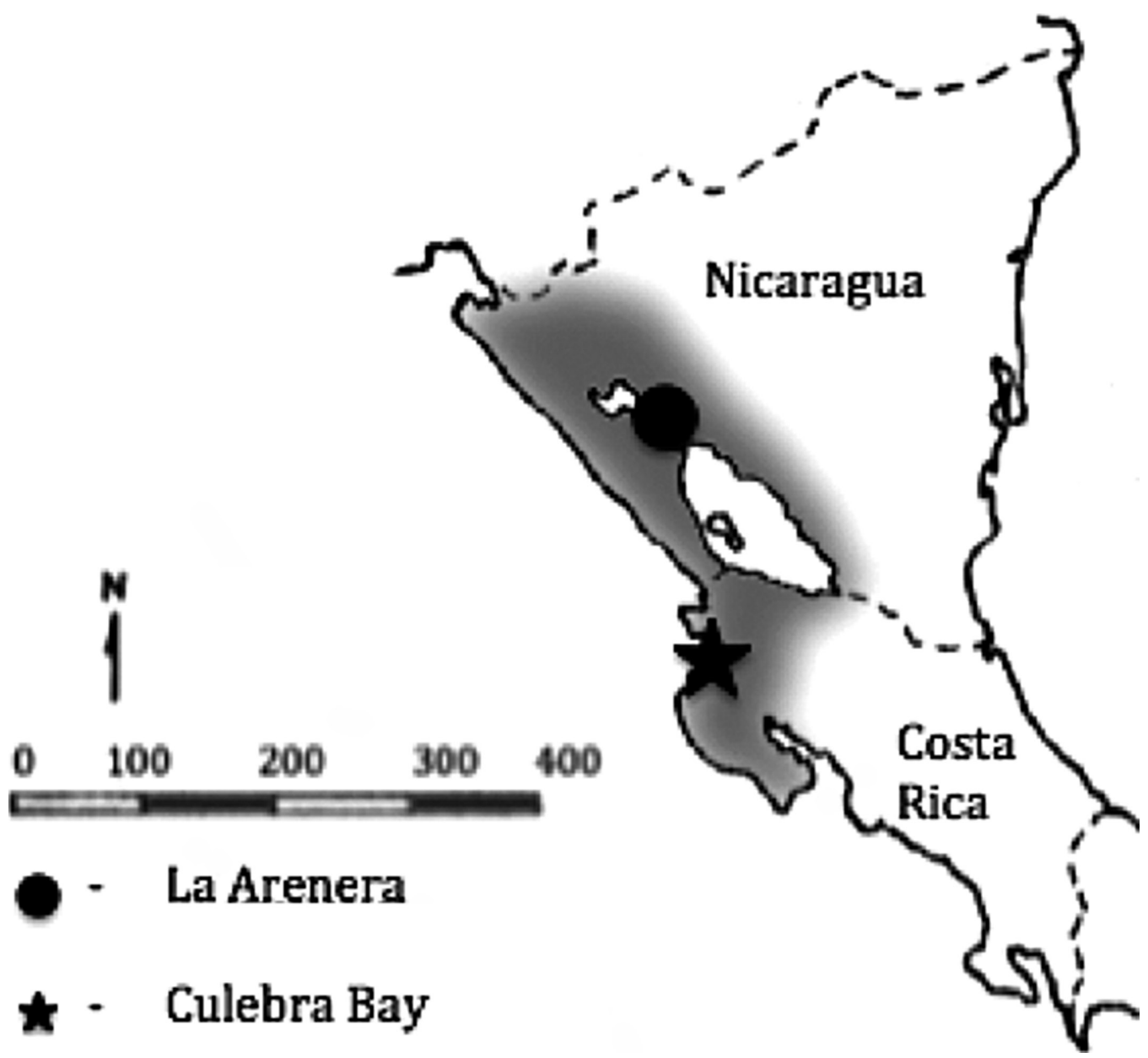

Figure 1: Map of Central America with Greater Nicoya region in grey.

\section{Petrographic research in Greater Nicoya}

The first major compositional study of ceramics from the Greater Nicoya region was carried out in the 1980s by Ronald Bishop and Frederick Lange. This massive undertaking focused primarily on the use of neutron activation analysis (NAA), but also included a cursory and comparative petrographic study in order to provide visual and mineralogical context for the chemical groupings established via NAA. This endeavour remains the most comprehensive ceramic compositional study to date for Greater Nicoya ceramics (Bishop et al., 1988; Bishop et al., 1992; Bishop \& Lange 2013). Formally known as the Greater Nicoya Ceramic Project (GNCP), the original sample set numbered more than 1,000 sherds selected from a wide cross-section of ceramics from both Pacific Nicaraguan (Isthmus of Rivas) and northwest Costa Rican (Guanacaste/Nicoya) 
areas of Greater Nicoya. The objective was to better understand the patterns and relationships between the manufacture and distribution of selected ceramic types throughout the Greater Nicoya region. The results demonstrated, with a great degree of certainty, that there were unique 'North' and 'South' sectors of ceramic manufacture and, for the most part, distribution.

Within Guanacaste, the GNCP noted chemical (NAA) composition differences between pottery groups from the Tempisque Valley (GN 05), the bays of Salinas and Culebra (GN 04), and the Rivas and Ometepe regions (GN 12 and GN 24) of Pacific Nicaragua (see Bishop et al. [1988] for details on the GN chemical groups). These groupings were further refined through petrographic comparison in order to define the mineralogical context in these differences (Bishop et al., 1988). The following is a short summary of the original key points of the study that assisted in localizing and understanding the geological differences between regions. The principal paste differences between the Northern and Southern sectors of Greater Nicoya involve the presence and quantities of different minerals and rocks, most of which are directly related to volcanic emplacement episodes in the area's history. For example, the petrographic component of the GNCP study found that high quantities of pumice appeared to represent tempered ceramics from the Rivas region (this interpretation has recently been refined, with the source of pumice-rich ceramic pastes likely being manufactured in, and distributed out of, the Granada area; see Dennett et al., 2012). The Southern Sector, on the other hand, is characterized by higher quantities of andesite, volcanic tuff and, in particular, hornblende, but with markedly low quantities of pumice (Bishop et al., 1988). The compositional groups representing the bays of Culebra and Salinas were associated with higher quantities of pyroxenes compared to other regions in Greater Nicoya (Bishop et al., 1988). High quantities of pyroxenes are a shared characteristic, likely due to the parent rock from an actively volcanic area, which encompasses a small territory to include the bays westward to the modern town of Rivas and Ometepe Island. In a subsequent compositional study undertaken by Dennett et al. (2011), it was noted that the Rosales Zone Engraved from La Arenera, located near Managua City, at the more northerly reaches of Greater Nicoya, lacked hornblende and was, instead, more closely associated with the mineralogy typically found along the Isthmus of Rivas, especially Ometepe Island. This comparative information was also taken into consideration during the current analysis of Rosales Zone Engraved sherds from both Loma Corral 3 and Manzanillo.

\section{The study sites}

The site of Loma Corral 3 is located in close proximity to Panama Beach and Ballena Point, near the southeast point of the bay; here archaeologists identified and developed the investigation in three stages. 'Loma Corral' was the first portion identified during the survey by Lange in the 1970s, followed by 'Loma Corral 2,' which the National Museum of Costa Rica identified below Loma Corral. Finally, 'Loma Corral

3' was identified during archaeological excavations carried out in 2005-2006 (Snarskis, 2013). The latter 
site, Loma Corral 3, is composed of a large cemetery that contained a wide range of artifacts, apparently untouched by looting. Guerrero (2007) suggests an occupation from 500 B.C. to 250 A.D. based on the ceramic types recovered, all of which are typical of the Tempisque period.

The site of Manzanillo is located on the opposite side of the bay and shows occupation ranging from the Orosi (2000-500 B.C.) through Sapoá (A.D. 800-1350) periods. First located through survey in the late 1970s (Lange et al., 1986), the site was excavated in various stages over several years (Sánchez, 2010; Solís, 1997). Early occupation is suggested by the presence of both Usulután, associated with the local Tronadora complex (300 - 200 B.C.), and Rosales Zone Engraved ceramics, associated with the local Bejuco phase (200 B.C. - 100 A.D.) (Sánchez, 2010).

The site of La Arenera, which provided comparative petrographic samples for this project, is located near the modern city of Managua, Nicaragua. Geoffrey McCafferty and Silvia Salgado directed the preliminary survey and excavations of the site in 2000 (McCafferty \& Salgado, 2000). The site is relatively large, covering an area of approximately $1 \mathrm{~km} 2$ and, due to volcanic emplacement episodes in the recent past, the site remained fairly well preserved with high quantities of Usulután and Rosales Zone Engraved ceramics from the Tempisque period.

\section{Ceramic types}

\section{The Usulután ceramic type}

Negative-resist decorated ceramics are known from many pottery-producing cultures across the Americas. Lange et al. (2003) provide an in-depth discussion on the variations in Usulután techniques observed in Central America. Traditionally this technique involves the application of a wax, tree pitch, or other sticky organic substance to create a decoration (usually in geometric designs) on the surface of a slipped vessel. Once the decoration has been achieved, a second coat of paint in a contrasting colour is applied over the entire surface prior to firing. In the firing process the fixed organic decoration is burned off, leaving a 'negative' imprint of original decoration on the now-exposed layer of slip. Usulután, for the purposes of this study, refers not only to a specific ceramic type originating in El Salvador, but also to the use of this negative-resist technique in surrounding areas that resulted in similar looking, though not authentic, pottery. As such, Usulután can be classified into three basic categories: (1) an "authentic" version, with many variants across time, manufactured in and distributed outward from El Salvador and western Guatemala, with a discernable style of negative-resist technique and paste composition (the traditional Usulután Ceramic Sphere); (2) a somewhat later, but contemporaneous and wide-spread manufacture of "Usulután-style" vessels across west-central Honduras (the Uapala Ceramic Sphere), again with unique paste compositions; 


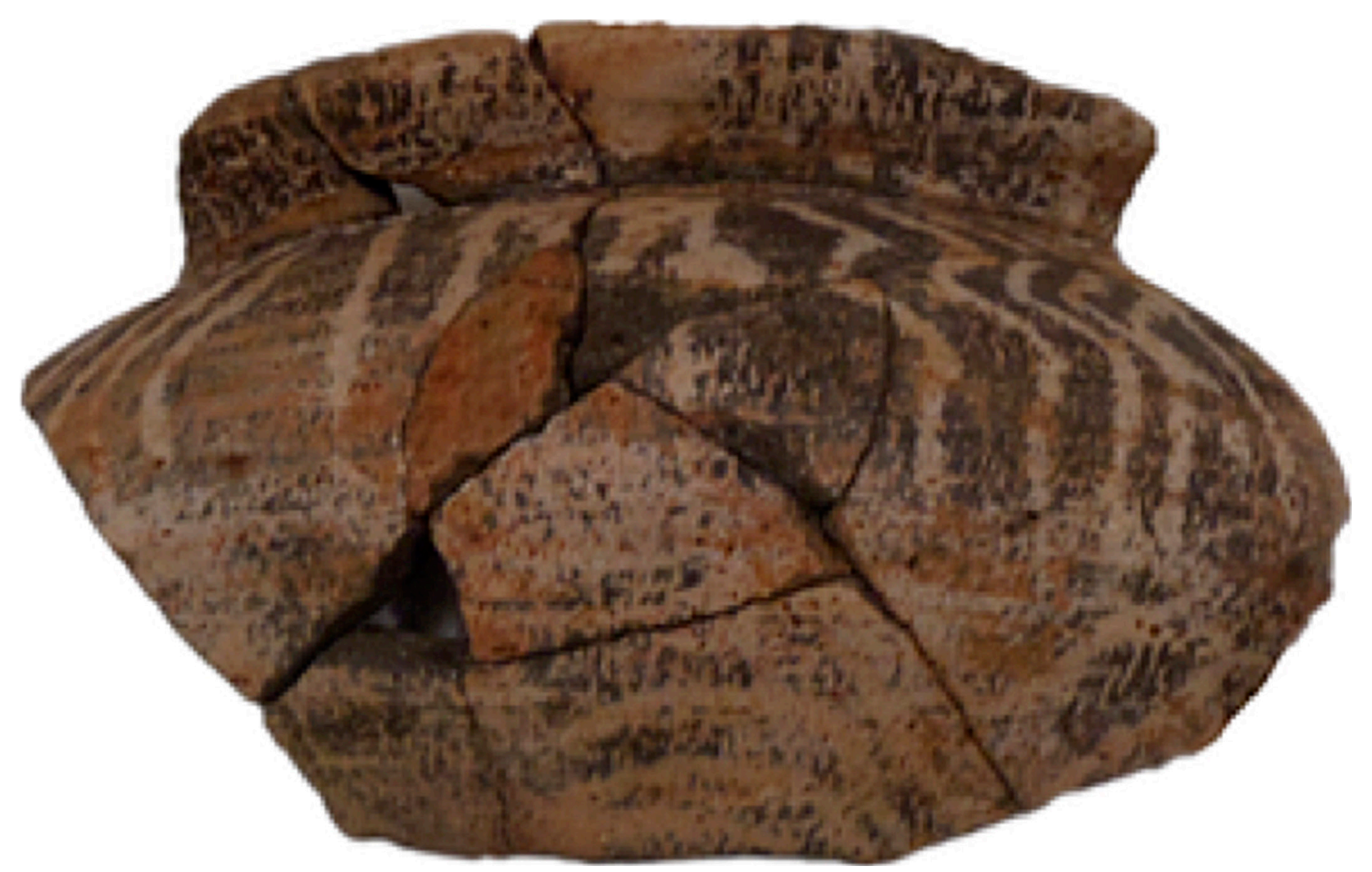

Figure 2: Example of Usulután recovered from Loma Corral 3 (Platz, 2014).

and, (3) "Usulután-like" manufacture in Pacific Nicaragua that imitates and/or emulates the decorative technique of the first group but utilizing local raw materials (Lange et al., 2003). In following with Lange et al. (2003), the term "Usulután-like" used here generally refers to ceramics that are decoratively similar to the Usulután-style vessels of the Uapala and Usulután Ceramic Spheres, but are not directly related in terms of exchange relationships or raw material. An example of this can be seen in the Usulután recovered from Loma Corral 3 (see Figure 2), which was originally interpreted as an exchange product originating from El Salvador (Guerrero, 2007; Snarskis, 2013). The results of this study, however, challenge that assumption through petrographic analysis.

In a study by Goralski (2008), numerous Usulután samples were subject to petrographic analysis, but it was found that the minute size of the mineral inclusions made the analysis nearly impossible. Instead, NAA was utilized for the final analysis and provided much more successful results. As I began the present study this was of particular concern, especially given that the Usulután from Loma Corral 3 was thought to have originated from El Salvador (Guerrero, 2007; Snarskis, 2013). However, the successful analysis of 
Usulután sherds from the La Arenera study suggested that if the Usulután from Culebra Bay was of local manufacture, that petrographic analysis would be possible, and that if it was potentially from El Salvador, the petrography would be impossible to conduct, as a first line of inquiry.

\section{The Rosales Zone Engraved ceramic type}

Rosales Zone Engraved is a highly diagnostic Tempisque period ceramic style from Greater Nicoya and is considered one of the most important and popular ceramic types of the period (Healy, 1980). The signature decorative technique consists of post-fired engraving and black paint on a well-burnished red slip, with the designs generally consisting of well-executed geometric patterns or animals (Healy, 1980). Like Usulután, Rosales Zone Engraved is also found to have figurine and effigy forms. Figure 3 shows two joined fragments with a clear black geometric or animal design recovered from Loma Corral 3.

As stated previously, NAA and petrographic analyses suggest the Isthmus of Rivas, Nicaragua, as one of the principal areas of Rosales manufacture. The fabric forms a distinct group containing high quantities of iron-stained clay and pumice inclusions (Bishop et al., 1988). As expected, high quantities of ironstained pumice were noted in the Rosales Zone Engraved samples from La Arenera (Dennett et al., 2011). Comparatively speaking, however, the sample set from this investigation did not exhibit the high quantities of iron-stained pumice inclusions seen in Nicaragua. The study by Bishop et al., (1988) did not include Rosales Zone Engraved samples from the Southern Sector of Greater Nicoya, thus it is not certain that manufacture occurred only in the North.

\section{Methodology}

For this preliminary study, the methodology was divided into three basic sections: macroscopic observation and selection of the sample set, preparation of the samples, and, finally, microscopic observation and comparison observation. As the Usulután and Rosales Zone Engraved ceramic types were predetermined for this study based on the author's previous work on these types from Nicaragua (Dennett et al., 2011), the selection of sherds was based on similarities in paste colour and larger mineral inclusions that were visible with a hand lens (10x). A total of six Rosales Zone Engraved and three Usulután sherds were selected from Manzanillo, and five of Rosales Zone Engraved and five of Usulután from Loma Corral 3. As a control group, a selection of Ballena Incised $(n=5)$ ceramics from Loma Corral 3, as well as a set of monochrome $(n=5)$ sherds from Manzanillo, were selected as a control and to assist in identifying potential local manufacture.

Samples were prepared through the Laboratory of Petrography in the Geology Department of the University of Costa Rica. This process involved standard slide preparation in which the sherds were cut and

ground down to a $30 \mu \mathrm{m}$, and then mounted onto slides with transparent epoxy. During production a blue 


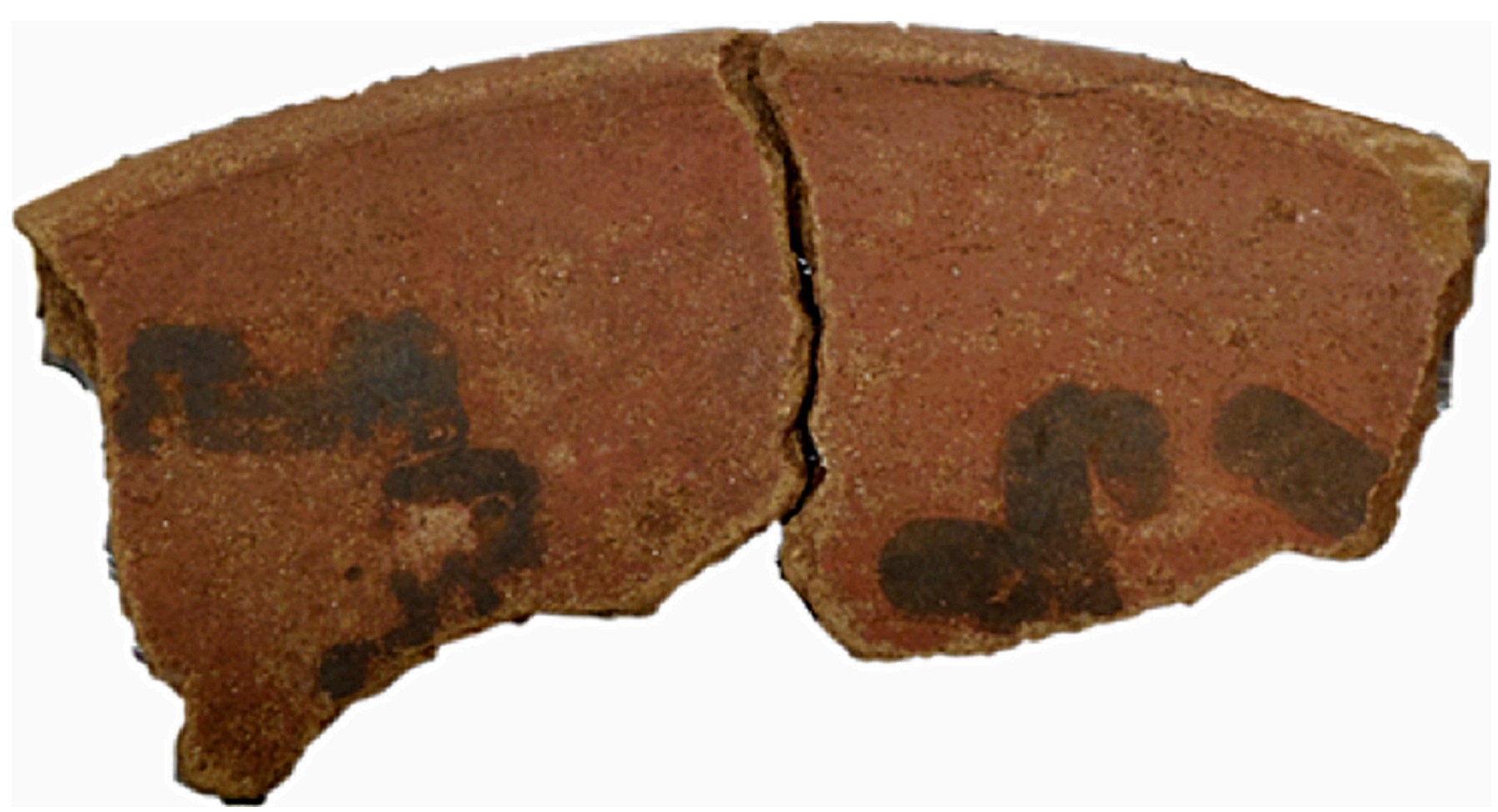

Figure 3: Rosales Zone Engraved plate fragments recovered from Loma Corral 3 (Platz 2014).

mineral material (grit) from the grinding process contaminated several of the slides; once this was noted it did not affect the interpretive value of the pre-existing minerals and was simply ignored in observation.

The microscopic analysis consisted of qualitative and semi-quantitative observations. Qualitative observations were noted using guidelines found in Reedy (2008) for mineral characteristics for proper identification. Visual percentage estimations were also made for each identified mineral and/or lithic in order to determine dominant and accessory types. Semi-quantitative analysis consisted of point-counting each thin section at selected grid intervals (see Reedy, 2008; Stoltman, 1989). Thin sections were enlarged, on average by $800 \%$, and a $1 \mathrm{~cm}$ grid was superimposed on each colour copy for interval point counting, where inclusion type (rock, mineral, matrix, or void) and size (silt, sand, or gravel) was recorded. For the purposes of intra-study consistency, the methodology utilized for the La Arenera study was also used for this investigation. Full methodological description can be found in Dennett, et al. (2011) and Platz (2014). The collective qualitative and semi-quantitative dataset assisted in determining standardization of manufacture recipes and potential regions of manufacture, as well as objectively demonstrating the similarities and differences within and between paste groups. 
Table 1: Summary of the dominate and accessory mineral types from local ceramic pastes at Loma Corral 3 and Manzanillo (based on Platz [2014]).

\begin{tabular}{cc}
\hline Types of dominant minerals & Types of accessory minerals \\
\hline Plagioclase Feldspar & Olivine \\
Quartz & Augite \\
Opaque Minerals (hematite, magnetite, etc.) & Pyroxenes \\
Hornblende & \\
Olivine (in the case of Usulután from Loma Corral 3) & \\
Pyroxenes (in the case of Usulután from Loma Corral 3) & \\
\hline
\end{tabular}

\section{Results}

Table 1 is a summary of the dominant and accessory minerals present in the six different paste groups. Interestingly, olivine and other pyroxenes were noted as dominant minerals only in the Usulután group from Loma Corral 3. Dominant minerals were classified as such if they were the most frequently occurring minerals within a particular paste group, thus accessory minerals included the mineral types that did not occur in great quantities or in all samples within a particular ceramic type. The percentages of each mineral type vary depending on the paste group and, in general, accessory minerals percentages were less than 5\% of the sample (see Platz [2014] for detailed percentage breakdowns).

The Usulután group from Loma Corral 3 is unlike the other paste groups from Loma Corral 3 and Manzanillo. It is unified paste group characterized by zoned pyroxenes, sub-angular inclusion form, and the grain size average includes matrix (51\%), silt (46\%), and sand (3\%). The Usulután group from Manzanillo is a somewhat unified group that is unique from the Usulután from Loma Corral 3. The paste group contains greater levels of variation in the recipe, and ranges in inclusion form from sub-angular to round, the grain size average includes matrix (54\%), silt (44\%), and sand (2\%).

The Rosales Zone Engraved group from Loma Corral 3 is very similar to the same ceramic type from Manzanillo. Collectively they are characterized by the presence of skeletal quartz, sub-angular to round inclusion form, and the presences of a higher quantity of larger size hornblende inclusions. The grain size average for the Rosales Zone Engraved group from Loma Corral 3 includes matrix (27\%), silt (67\%), and sand (6\%). The grain size average for the Rosales Zone Engraved group from Manzanillo includes matrix $(27 \%)$, silt (69\%), and sand (4\%).

The samples of Usulután from Loma Corral 3 were petrographically distinct from all of the other samples analyzed from both Loma Corral 3 and Manzanillo, suggesting that it was not manufactured locally. Of 


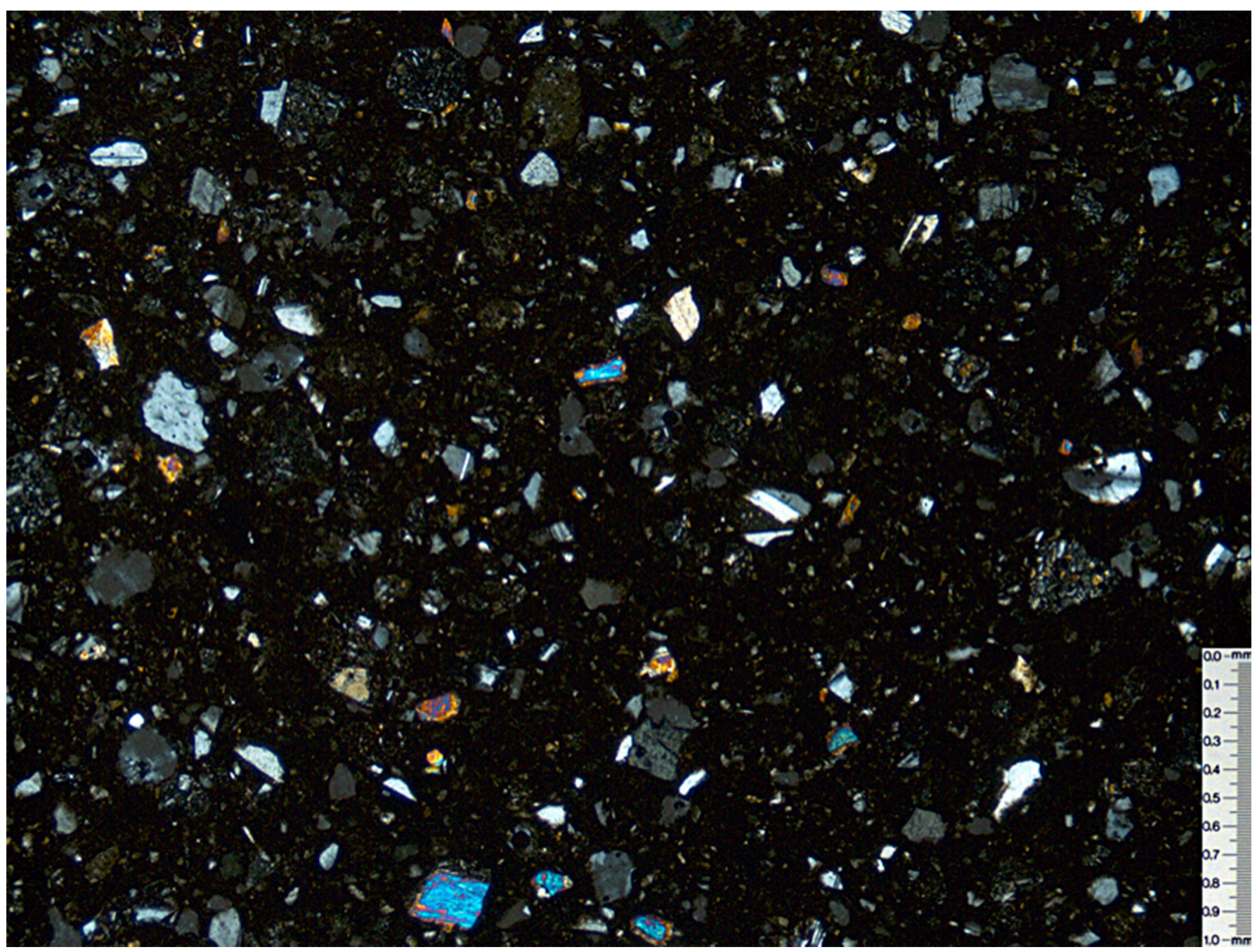

Figure 4: Usulután (sample \#cde1-2) from Loma Corral 3; 4x under cross-polarized light (Platz 2014).

perhaps greatest interest, was that the Usulután from Loma Corral 3 exhibited a compositional paste profile very similar to some of the Usulután samples from La Arenera, in Nicaragua (see Platz [2014] for details). Figures 4 (Loma Corral 3) and 5 (La Arenera, Nicaragua) demonstrate the similarities between Usulután ceramic pastes under cross-polarized light. The more-angular inclusions in this paste group also suggest formal process in material preparation, especially when compared to the other paste groups associated with Loma Corral 3 and Manzanillo. The apparently nonlocal Usulután group from Loma Corral 3 is more closely associated to a parent geological region more mafic in nature (meaning clay derived from rocks with greater iron and magnesium levels than those in Nicoya). Samples suggest association with a volcanic region of basaltic to andesitic nature. 


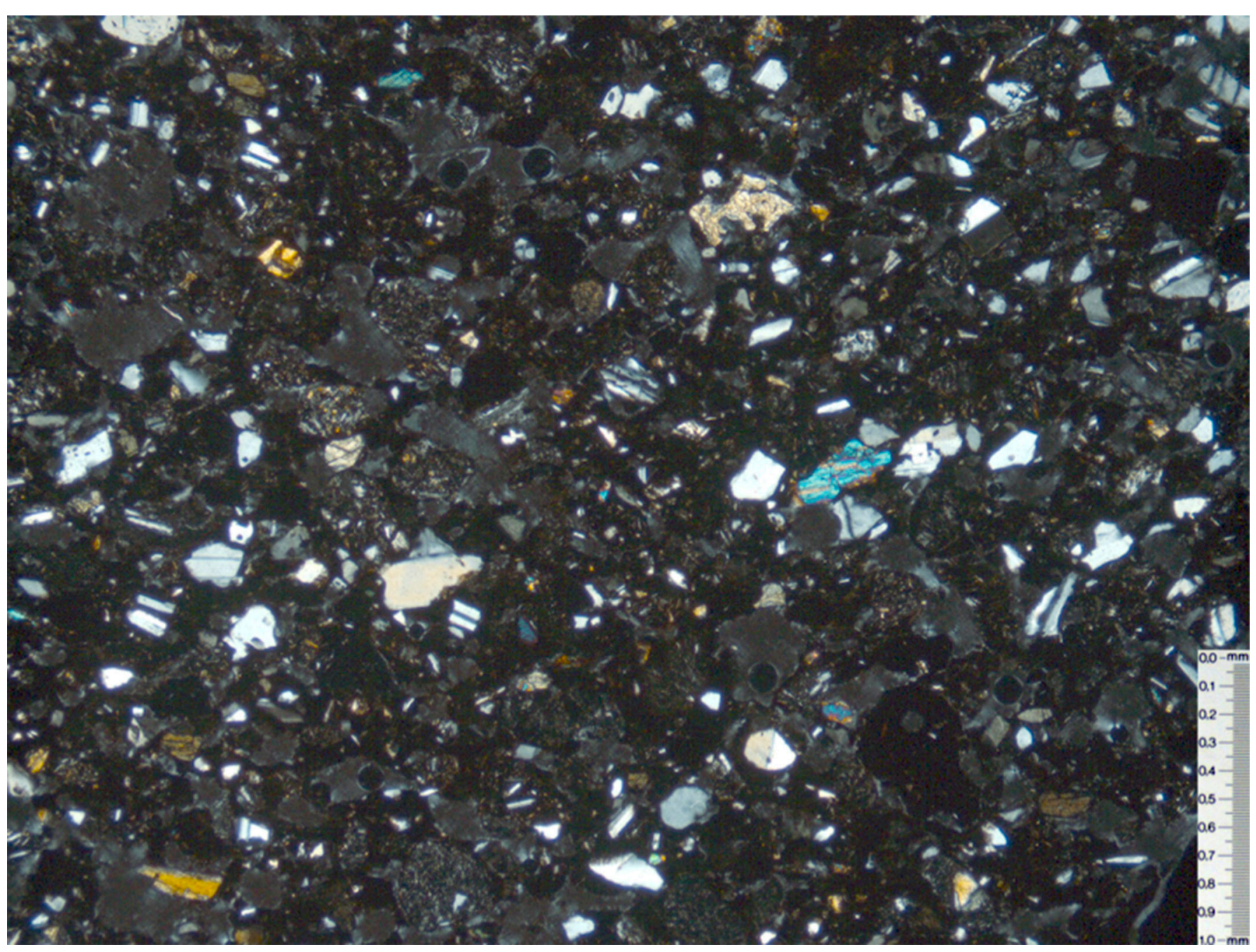

Figure 5: Usulután (sample \#AR9) from La Arenera; 4x under cross-polarized light (Platz 2014).

The remaining paste groups, which include both of the Rosales Zone Engraved groups, Ballena Incised, and the monochrome samples, all have similar mineralogical composition with minor variations in the petrofabric ${ }^{2}$, suggesting that they probably originated from the same general geological zone. The point-counting suggests a great degree of inter-sample variation (see Platz [2014] for a more detailed explanation), but when combined with the qualitative results it becomes readily apparent that they are perhaps

2 The author uses the term 'petrofabric' as referring to the microscopic features of rock fabric, this includes the variety of minerals and rocks, their form, and size. 


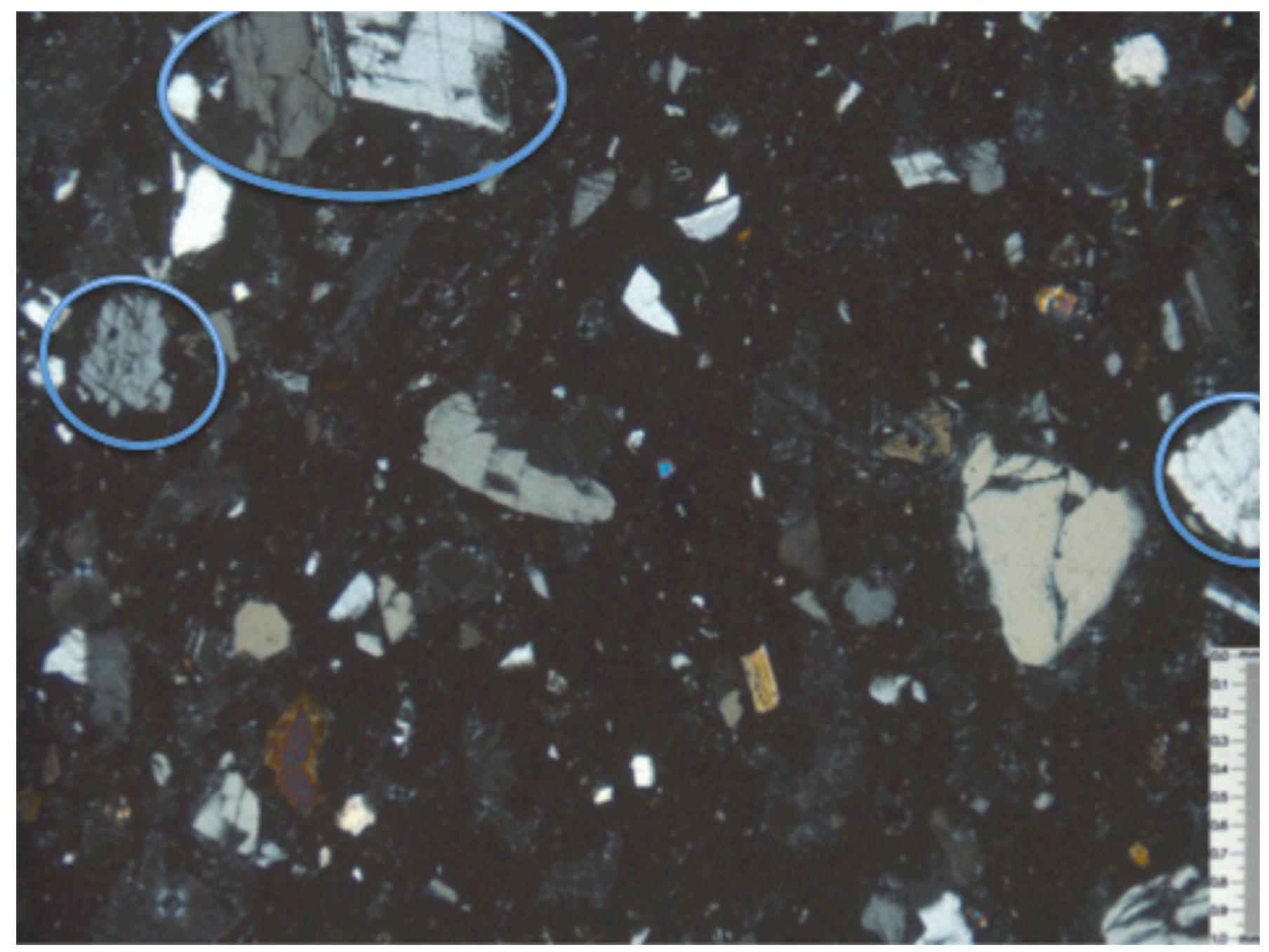

Figure 6: Monochrome (sample \#G430MZ) from Manzanillo; 4x under cross-polarized light (Platz 2014).

simply from different artisan groups or communities, or from different clay source locations within the same geological region. One interesting feature of many paste group samples was the presence of 'skeletal,' or decomposing, quartz inclusions, most clearly represented in Figures 6 and 7 (highlighted by the blue circles). These skeletal minerals suggest clays derived from sources that have undergone more long-term 


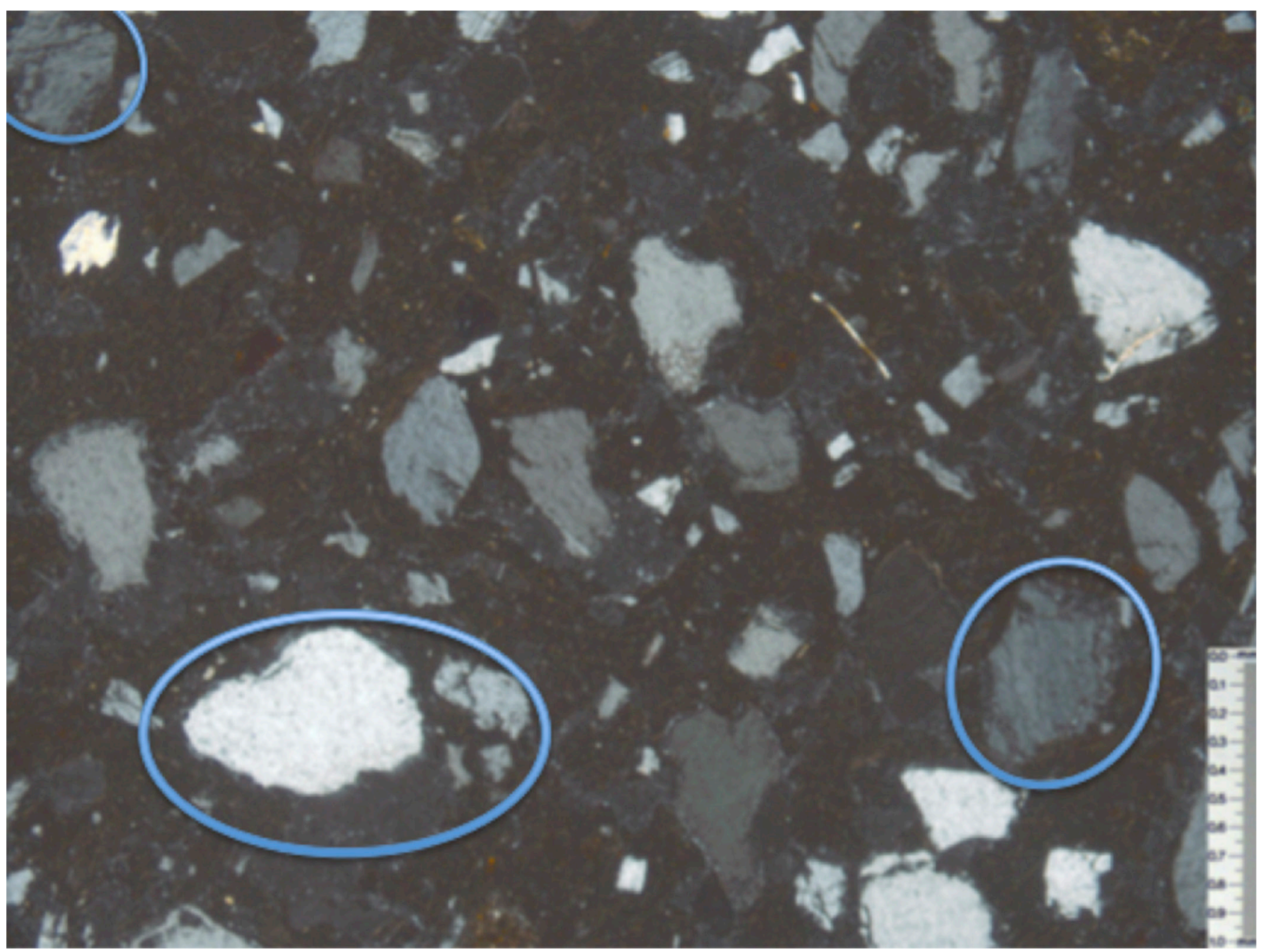

Figure 7: Rosales Zone Engraved (sample \#2098) from Manzanillo; 4x under cross-polarized light (Platz 2014).

weathering and/or decomposition events (in or outside of the volcano that produced them) than those seen in the Usulután paste from Loma Corral 3. The mineralogical composition of this "local" group suggests a parent environment of igneous origin with more intermediate characteristics, one that is more felsic to andesitic in nature - much like that which occurs in the area of Culebra Bay. 


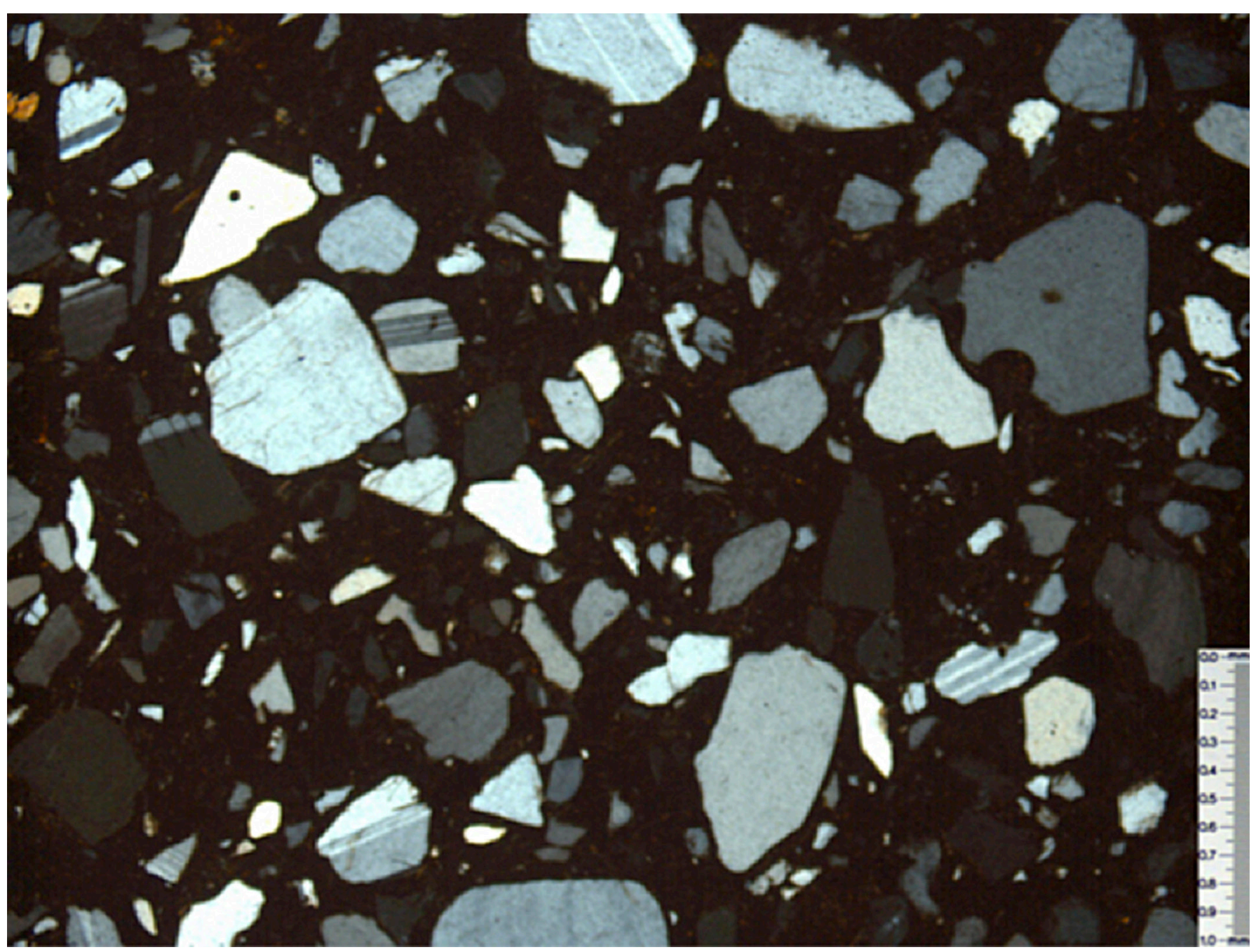

Figure 8: Rosales Zone Engraved (sample \#R37C3-10) from Loma Corral 3; 4x under cross-polarized light (Platz 2014).

Figures 8 and 9 show the noticeable difference in paste composition between Rosales Zone Engraved sherds from Loma Corral 3 and those from La Arenera. Larger, rounder inclusions were present in higher quantities in the samples from Loma Corral 3 and Manzanillo, which may suggest a secondary deposit location from which the raw material for manufacture was extracted. It is extremely important to note the high frequency of large hornblende inclusions in the samples from Loma Corral 3 and Manzanillo. It is particularly important because the presence of hornblende is diagnostic of the Guanacaste-Nicoya area, and also serves to differentiate these from the La Arenera samples where amphiboles occur in trace quantities, at best, and high quantities of naturally occurring opaque minerals, especially hematite, is a primary diagnostic. 


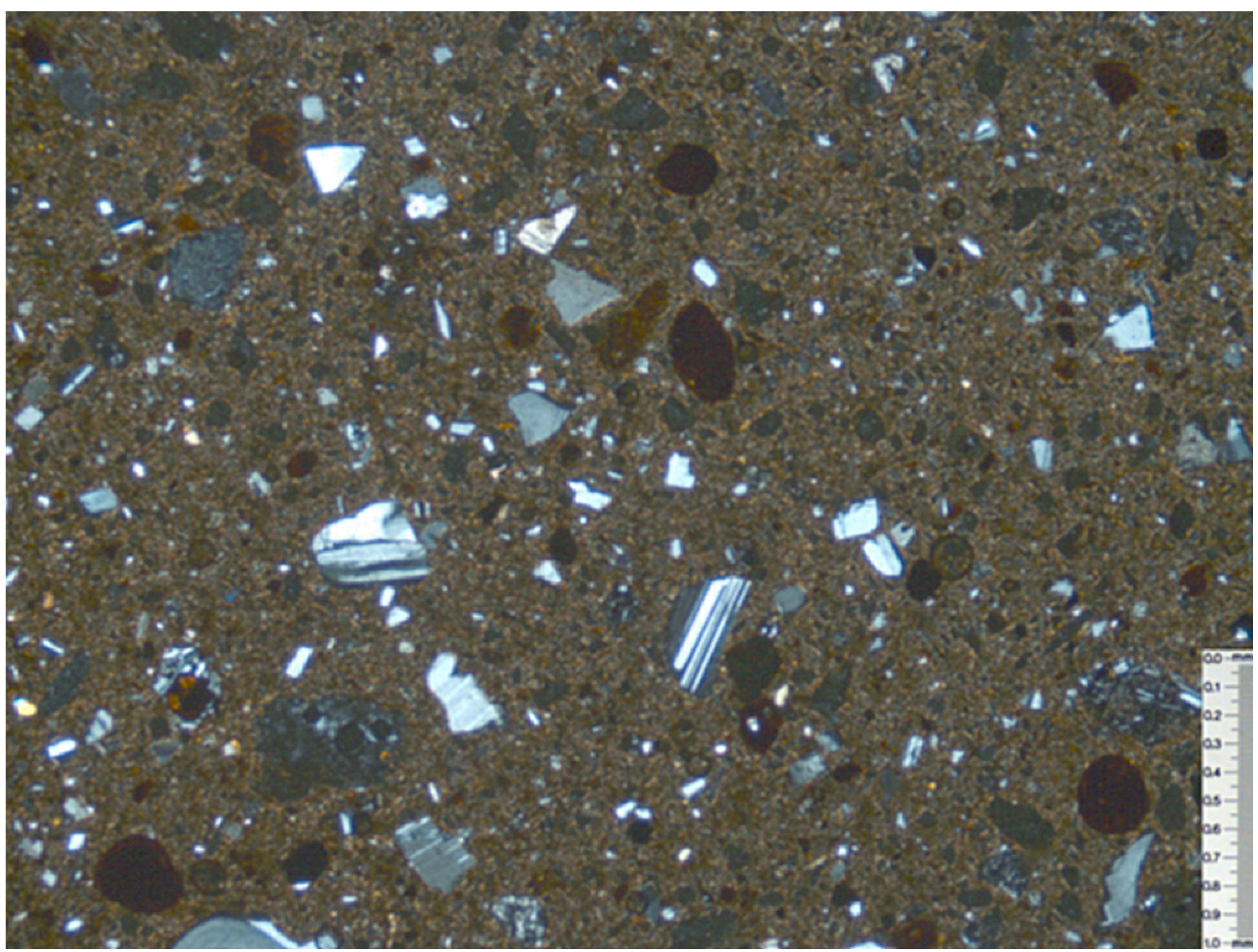

Figure 9: Rosales Zone Engraved (sample \#AR15) from La Arenera ; 4x under cross-polarized light (Platz 2014).

High quantities of large-sized hornblende inclusions are present in Rosales Zone Engraved from the Culebra Bay sites. Figure 10 demonstrates the predominant size of the hornblende inclusions commonly found in these and many of the other local samples. In re-examining the original samples from the GNCP study, Loma Corral 3 and Manzanillo still contained higher quantities of hornblende compared to the other regions (especially NAA groups GN 05 from the Tempisque Valley, GN 12 and 24 from the Rivas region, and GN 14 from the Guanacaste region). As further studies are performed, this variation in hornblende ratios could be used to further narrow down the manufacturing range within the Southern Sector of Greater Nicoya. 


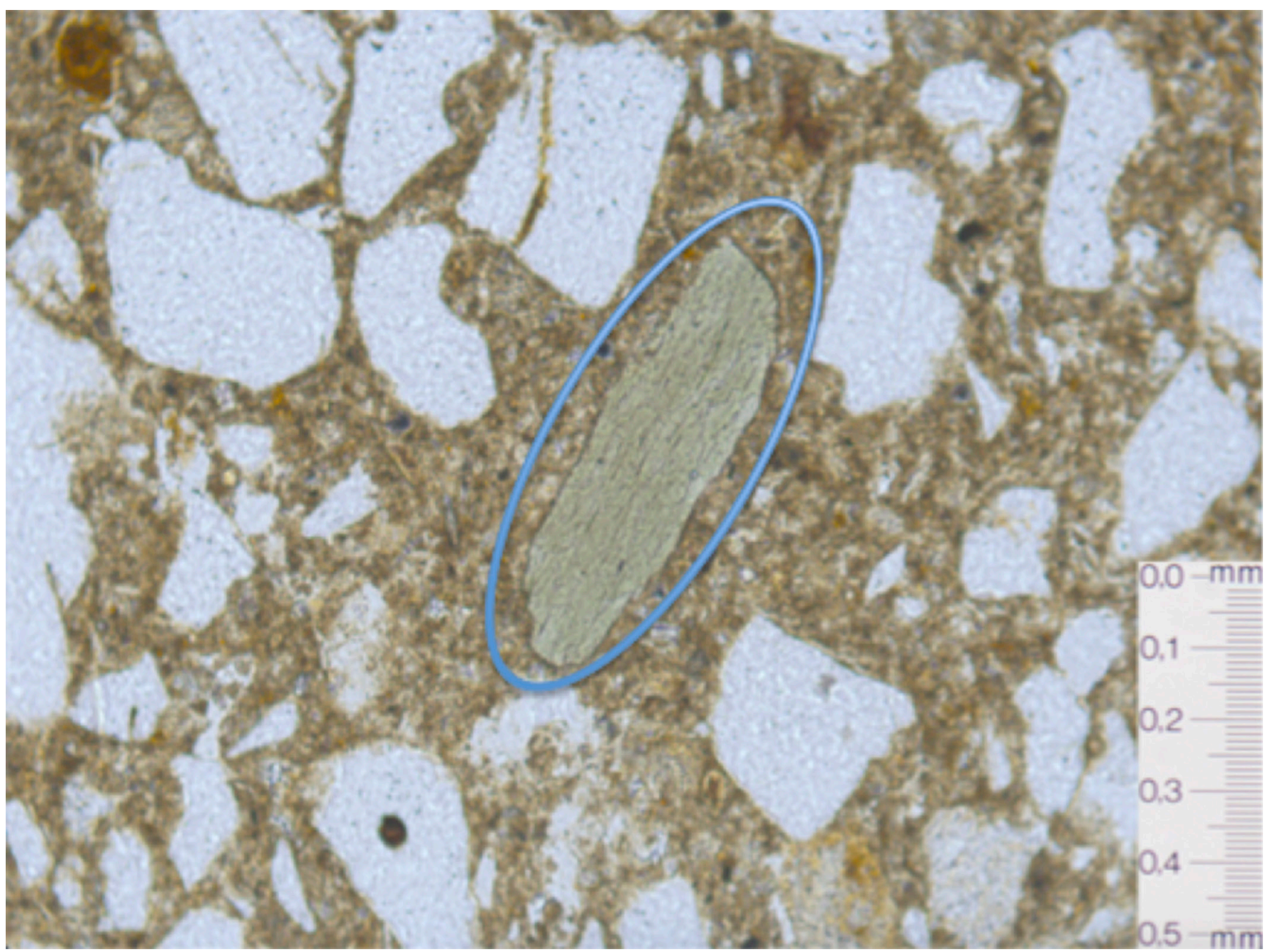

Figure 10: Hornblende (highlighted by the blue circle) present in sample \#R37C3-10; 10x under plane-polarized light (Platz 2014).

The group of Usulután from Manzanillo are not unified in terms of their mineralogical composition or in terms of the inclusion size compared to the other ceramic types. In part, the small sample size does not allow for a strong comparative assessment, though these individual samples were compared to the other groups and appeared to share more similarities with the Rosales Zone Engraved, Ballena Incised, and the monochrome groups. Perhaps suggesting that there may have been some regional manufacture of a negative-resist ceramic type, though more studies are necessary to confirm this idea. Ideally, chemical analysis would be the preferred method to confirm this, though it seems apparent that additional petrographic studies with larger sample sizes could be used as a successful and cost-effective method. 


\section{Discussion/Conclusion}

The results of this analysis suggest an association between the Usulután from Loma Corral 3 and that from La Arenera, Nicaragua, and this is very important for several reasons. First, this contradicts traditional stylistic interpretations that assume an El Salvadorian origin for Usulután ceramics in Nicoya, as suggested most recently by Snarskis (2013) and Guerrero (2007). Although this is a preliminary study, the resulting information supports for the need for increased compositional analyses for defining ceramic types and manufacture zones rather than simply relying on decorative style identifications to speculate on origins. The correct identification of a decorative style is still important in selecting the samples for compositional analysis. There are further implications in terms of understanding how ceramic manufacturing centres or spheres may have expanded and contracted during different pre-Columbian periods. The results of this study suggest that the Managua region was perhaps the southern limit for the manufacture of Usulután-style vessels for a short period of time after A.D. 1/100. Whether the artisans of the Uapala Ceramic Sphere expanded into the Managua region, or artisan groups from the Managua region travelled north to learn the technique, it has yet to be determined without additional archaeological support. The strong similarities in the mineralogical composition, as well as vessel forms, suggest that a particular artisanal community manufactured Usulután in the Managua region for both local consumption and for exchange with external groups.

Conversely, the Usulután samples from Manzanillo show the presence of a negative-resist decorative technique being used locally, by artisans in the Guanacaste region who understood the technical aspects of manufacturing this type of ware (Hardy, 1992; Stone, 1977), though more studies are required to confirm this interpretation. When discussing the negative-resist technique, one needs to remain cautious in the terminology used to describe the decoration until further studies can determine if there was local manufacture or exchange with foreign groups.

The Rosales Zone Engraved, Ballena Incised, and monochrome groups present a slightly wider range of variation in mineral composition types and inclusion sizes. These slight variations are also reflected by the slightly larger than expected range of grain sizes, as ascertained in the point-counting analysis, especially when compared to the nonlocal Usulután from Loma Corral 3 (Platz, 2014). This does not suggest different manufacturing regions. Rather, it appears to be the result of different artisans or ceramic communities manufacturing these three types. Given the coastal location of the sites, the high degree of weathering and/or decomposition inherent in the mineralogy of the clays provides additional support for the possibility of having obtained the raw material locally. There is a relative consistency between samples with coarse petrofabric and, in the case of Ballena Incised and the monochrome wares, a slightly crumbly fabric. The variation present in the Rosales Zone Engraved samples from Loma Corral 3, Manzanillo, and La Arenera provide further support for the pan-regional manufacture of this ceramic type in the Tempisque period, although more analyses from additional sites are required to confirm this argument. 
Given the wide range of goods from the site of Loma Corral 3, it requires a discussion of what types of exchange the groups on Culebra Bay participated in with other regions. There are two general threads: first is the movement of Usulután from the Managua region to Loma Corral 3 and, second, is the involvement of Rosales Zone Engraved producing groups and their potential relationship to producers on the Isthmus of Rivas to the north. In the case of the Usulután from Loma Corral 3, this study contradicts previous interpretations by Snarskis (2013) and Guerrero (2007) that assume this ceramic type originated from El Salvador based on decorative analysis. The lack of large quantities of Usulután throughout Greater Nicoya would appear to show support for a gift based exchange system directly between the manufacturers and consumers.

In the case of Rosales Zone Engraved, I take into consideration the NAA and petrographic studies by Bishop \& Lange (2013) that associated the manufacture of Rosales Zone Engraved with the Isthmus of Rivas. As the Rosales Zone Engraved from Loma Corral 3 and Manzanillo were not petrographically similar to the samples from La Arenera (which was associated with the Ithmus of Rivas; see Dennett et al., 2011), the exchange of final products is probably not what is being represented in this case. I propose instead that the exchange involved the technological knowhow rather than the final product between the Isthmus of Rivas and Culebra Bay. The Department of Rivas and Ometepe Island in the Northern Sector are probable candidates for the origin of manufacture of Rosales Zone Engraved, particularly based on important similarities in decorative techniques and macroscopic paste analysis. Based on the slightly crumbly nature of the paste, poor execution of the decoration, and the local composition, I argue that the Rosales Zone Engraved from Loma Corral 3 (e.g., see Figure 3) and Manzanillo was likely not an "authentic" Rosales group compared to samples recovered from sites in the Northern Sector, which in my opinion are superiorly manufactured. The vessel form, decorative style, and colour all suggest an in-depth knowledge of the ceramic type, which perhaps is the result of the centralization of the manufacturing and eventual dispersion of additional, or subsequent, manufacturing sites. Here I propose that artisans from the Isthmus of Rivas may have trained artisans from the Southern Sector of Greater Nicoya, and after having acquired the technique they were able to replicate the decorative style using local raw materials. Based solely on this preliminary study, it is difficult to determine if manufacture was directly occurring in the Culebra Bay area or elsewhere in the Southern Sector of Greater Nicoya.

Due to the concentration of Usulután present at Loma Corral 3, I argue for a special gift-based exchange system between the manufacturing group and the consumers. The lack of known Tempisque sites between Culebra Bay and the Managua region with high concentrations of Usulután may suggest this was an intentional, and perhaps controlled, relationship between the two groups. However, as a preliminary petrographic study it would be premature to imply a definitive method of exchange. For example, the site 
of Ayala, located in the Department of Granada, Nicaragua, contained Usulután-style ceramics as part of the Siu Phase (1-300/400 A.D.). Based on its geographical location and archaeological makeup, Ayala may have served as a midway point for exchange between Managua and Nicoya, and it should be included in future investigations (Salgado, 1992). I strongly believe that a more extensive study of Usulután is required utilizing a simpler conceptual method of determining exchange systems. At which point, a dendritic 'mindmap' style of plotting relationships between sites (see Platz [2014] for further explanation) will achieve a clearer understanding of the relationships between manufacturers and consumers. Until more extensive chemical and petrographic databases can be established for multiple sites containing targeted ceramic types, exchange models such as those proposed by Renfrew (1975) are perhaps not the most useful tools.

In summary, the preliminary petrographic analysis of Rosales Zone Engraved and Usulután from Loma Corral 3 and Manzanillo, including a comparative analysis with samples from La Arenera, presents several important interpretations regarding regional manufacture and exchange of ceramics. Additional studies using petrography and the eventual use of additional chemical analyses are important for further understanding of the regions of manufacture of Usulután and Rosales Zone Engraved.

\section{Acknowledgements}

Sincere thanks to Dr. Silvia Salgado of the University of Costa Rica and Ph.D. candidate Carrie Dennett of the University of Calgary, Canada, for their assistance. Thin sections for this study were completed within the Department of Petrography within the Geology School at the University of Costa Rica with the assistance of geologists Luis Obando Acuña and Stephanie Murillo Maikut. Gratitude is also expressed to the National Museum of Costa Rica and to archaeologists Juan Vicente Guerrero and Luis Sánchez Herrera.

\section{References cited}

Bishop, R. L., Lange, F. W. \& Lange, P. C. (1988). Ceramic paste compositional patterns in Greater Nicoya Pottery. En F. W. Lange (ed.), Costa Rican Art and Archaeology (pp 13-44). Boulder, Colorado: Universidad de Colorado Press.

Bishop, R. L., Lange, F. W., Abel-Vidor, S. \& Lange, P. C. (1992). Compositional characterization of the Nicaraguan ceramic sample. En F. W. Lange, P. D. Sheets, A. Martinez y S. Abel-Vidor (eds), The Archaeology of Pacific Nicaragua (pp. 135-162). Albuquerque, N.M.: The University of Nuevo México. 
Bishop, R. L. \& Lange, F. W. (2013). The prehispanic ceramic schools of Greater Nicoya. En M. Young-Sanchez (ed.), Pre-Columbian art and archaeology: Essays in honor of Frederick R. Mayer (pp. 27-46). Denver, Colorado: Denver Art Museum.

Dennett, C. L., McCafferty, G. G. \& Bishop, R. L. (2012). La vajilla cerámica Granada Roja. Mi Museo y Vos, 6(22), 7-11.

Dennett, C., Platz, L. \& McCafferty, G. (2011). Preliminary ceramic compositional analysis from La Arenera site, Pacific Nicaragua. La Universidad, 14-15, 373-398

Goralski, C. T. (2008). An examination of the Uapala-Usulutan ceramic sphere using Instrumental Neutron Activation Analysis (Unpublished doctorate thesis). The Pennsylvania State University, Pennsylvania, E.E.U.U.

Guerrero, J. V. (2007). Costumbres mortuorias y rituales funerarios de 2000 años Sitio Loma Corral (G776 LC-3), playa Panamá Carrillo, Guanacaste. Museo Nacional de Costa Rica, Departamento de Antropología e Historia (Unpublished manuscript).

Hardy, E. T. (1992). The mortuary behaviour of Guanacaste/Nicoya: An analysis of precolumbian social structure (Unpublished doctorate thesis). University of California, Los Angeles, California, E.E.U.U.

Healy, P. F. (1980). Archaeology of the Rivas Region, Nicaragua. Waterloo, O.N.: Wilifred Laurier Press,

Hirth, K. G. (1978). Interregional trade and the formation of prehistoric Gateway Communities. American Antiquity, 43(1), 35-45.

Lange, F. W, Ryder, P. \& Accola, R. M. (1986). Bay of Culebra Survey. Journal of the Steward Anthropology Society, 14(1-2), 25-36.

Lange, F. W., Sears, E. L., Bishop, R. L. \& Salgado, S. (2003). Local production, non-local production, and distribution: Usulután and Usulután-like negative painted ceramics in Nicaragua. In L. van Zeist (ed.), Patterns and processes: A festschrift in honor of Dr. Edward V. Sayre (pp. 157-172). Washington, D.C.: Smithsonian Center for Materials Research and Education.

Mauss, M. (1923). The gift: Forms and functions of exchange in archaic societies (Translation by Ian W. W. Gunninson). New York: Norton and Company Inc.

McCafferty, G. \& Salgado, S. (2000). Reporte preliminar de la evaluación del sitio La Arenera (N-MA-65) realizada del 4 al 8 de julio del 2000. Patrimonio Cultural, Instituto Nicaragüense de Cultura, Managua, Nicaragua (Unpublished manuscript).

Platz, L. (2014). Un sistema de intercambio macroregional en el period Tempisque (300 a.C. - 500 d.C.): Estructura composicional de tres tipos cerámicos encontrados en la bahía de Culebra, Costa Rica (Unpublished masters thesis). University of Costa Rica, San José, Costa Rica.

Reedy, C. L. (2008). Thin-Section petrography of stone and ceramic cultural materials. London: Archetype Publications Ltd.

Renfrew, C. (1975). Trade as action at a distance. In J. A. Sabloff and C. C. Lamberg (eds), Ancient civilization and trade (pp. 3-59). Alburquerque, N.M.: The University of Nuevo Mexico Press.

Salgado, S. (1996). Social change in a region of Granada, Pacific Nicaragua (1000 B.C. - 1522 A.D.) (Unpublished doctorate thesis). State University of New York, Albany, New York. 
Sánchez, L. A. (2010). Las ocupaciones tempranas en Bahía Culebra: Tecnología, subsistencia y utilización del espacio por comunidades costeras de los periodos Orosi Tardio y Tempisque (500 a.C. a 500 d.C.) en Manzanillo (G-430Mz), Península de Nacascolo, Guanacaste. Museo Nacional de Costa Rica, Departamento de Antropología e Historia (Unpublished manuscript).

Snarskis, M. (2013). Loma Corral 3, Culebra Bay, Costa Rica: An elite burial ground with jade and Usulután ceramic offerings. In M. Young-Sánchez (ed.), Pre-Columbian art and archaeology: Essays in honor of Frederick R. Mayer (pp. 46-82). Denver, Colorado: Denver Art Museum.

Solís, F. (1997). Nuevos datos en la arqueología de Bahía Culebra, Guanacaste, noroeste de Costa Rica. Vínculos, 22, 1-44.

Stoltman, J. B. (1989). A quantitative approach to the petrographic analysis of ceramic thin sections. American Antiquity, 54(1), 147-160.

Stone, D. (1977). Pre-Columbian man in Costa Rica. Cambridge, Massachusetts: Harvard University Press. 
